3. Sturm W, Fimm B, Cantagallo A, et al. Specific computerised attention training in stroke and traumatic brain-injured patients: a European multicenter efficacy study. Z Neuropsychol 2003;14:283-292.

4. Diener HC, Weimar C, eds. Leitlinien fur Diagnostik und Therapie in der Neurologie. Stuttgart: Thieme; 2012.

\section{INFLUENZA VACCINATION AND CARDIOVASCULAR RISK IN PATIENTS WITH RECENT TIA AND STROKE}

Bayzidur Rahman, Anita Heywood, Aye Moa, C. Raina MacIntyre, Sydney, Australia: Lavallée et al. ${ }^{1}$ found no effect of influenza vaccination on risk of cardiovascular disease in recent TIA or stroke patients. Vaccination status was determined by baseline self-report, which has poor validity and is subject to recall bias. ${ }^{2}$ This can result in misclassification of vaccination status and bias of the reported effect.

Vaccination timing was not presented in the 3 component studies. Survival analysis was conducted on a baseline vaccination status for any cardiovascular event occurring during the 2-year follow-up. Without annual vaccination data, it is unknown whether participants were protected by vaccination at the time of subsequent cardiovascular events.
The pooling of data from 3 separate studies for the main analyses is not ideal. The analyses should appropriately consider between-study variation (e.g., individual patient data meta-analysis). ${ }^{3}$ Two of the component studies (OPTIC and PERFORM) were multicentered (clustered), which also warrants consideration. This study failed to show an unbiased effect of vaccination on cardiovascular events, which conflicts with data showing such an effect. ${ }^{4,5}$

(C) 2014 American Academy of Neurology

1. Lavallée PC, Labreuche J, Fox KM, et al. Influenza vaccination and cardiovascular risk in patients with recent TIA and stroke. Neurology 2014;82:1905-1913.

2. Rolnick SJ, Parker ED, Nordin JD, et al. Self-report compared to electronic medical record across eight adult vaccines: do results vary by demographic factors? Vaccine 2013;31:3928-3935.

3. Riley RD, Lambert PC, Abo-Zaid G. Meta-analysis of individual participant data: rationale, conduct, and reporting. BMJ 2010;340:c221.

4. Udell JA, Zawi R, Bhatt DL, et al. Association between influenza vaccination and cardiovascular outcomes in high-risk patients: a meta-analysis. JAMA 2013;310: 1711-1720.

5. Warren-Gash C, Smeeth L, Hayward AC. Influenza as a trigger for acute myocardial infarction or death from cardiovascular disease: a systematic review. Lancet Infect Dis 2009;9:601-610.

\title{
CORRECTIONS
}

\section{MRI measurement of brain iron in patients with restless legs syndrome}

In the article "MRI measurement of brain iron in patients with restless legs syndrome" by R.P. Allen et al. (Neurology ${ }^{\circledR}$ 2001;56:263-265), there is an error in the author byline. The third author's name should read "F.W. Wehrli, PhD."

\section{Child Neurology: PRRT2-associated movement disorders and differential diagnoses}

In the article "Child Neurology: PRRT2-associated movement disorders and differential diagnoses" by D. Ebrahimi-Fakhari et al. (Neurology $\left.{ }^{\circledR} 2014 ; 83: 1680-1683\right)$, there is an error in the footnote under table 1. Table 1 is not reproduced from Gupta and Lang but was created by the authors. Supplemental table e-2 was modified from Gupta and Lang (Gupta A, Lang AE. Psychogenic movement disorders. Curr Opin Neurol 2009;22:430-436), with permission. The authors regret the error.

\section{CD49d antisense drug ATL1102 reduces disease activity in patients with relapsing-remitting MS}

In the article "CD49d antisense drug ATL1102 reduces disease activity in patients with relapsing-remitting MS" by V. Limmroth et al. (Neurology ${ }^{\circledR}$ 2014;83:1780-1788), there is an error in the Acknowledgment section: "Prof. Krzysztof" should read "Prof. Selmaj" and "Dr. Strangel" should read "Dr. Stangel." In addition, the first sentence in the Methods under "Safety data" should read: "Safety was evaluated by an independent data safety monitoring board on the basis of adverse events, laboratory data, vital signs, MRI assessment for PML, physical examination, 12-lead ECG, and local tolerance." The authors regret the errors. 


\section{Neurology}

Child Neurology: PRRT2-associated movement disorders and differential diagnoses
Neurology 2015;84;105

DOI 10.1212/WNL.0000000000001144

This information is current as of December 29, 2014

$\begin{array}{ll}\begin{array}{l}\text { Updated Information \& } \\ \text { Services }\end{array} & \begin{array}{l}\text { including high resolution figures, can be found at: } \\ \text { http://n.neurology.org/content/84/1/105.3.full }\end{array} \\ \text { Permissions \& Licensing } & \begin{array}{l}\text { Information about reproducing this article in parts (figures,tables) or in } \\ \text { its entirety can be found online at: } \\ \text { http://www.neurology.org/about/about_the_journal\#permissions }\end{array} \\ \text { Reprints } & \begin{array}{l}\text { Information about ordering reprints can be found online: } \\ \text { http://n.neurology.org/subscribers/advertise }\end{array}\end{array}$

Neurology ${ }^{\circledR}$ is the official journal of the American Academy of Neurology. Published continuously since 1951, it is now a weekly with 48 issues per year. Copyright (C) 2014 American Academy of Neurology. All rights reserved. Print ISSN: 0028-3878. Online ISSN: 1526-632X.

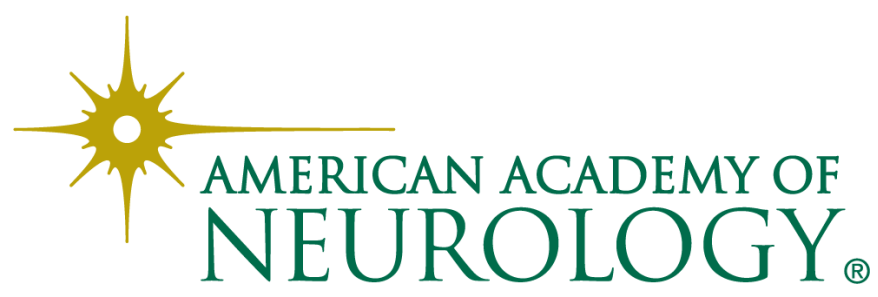

